\title{
An assessment of heavy metal contamination in the marine soil/sediment of Coles Bay Area, Svalbard, and Greater Bay Area, China: a baseline survey from a rapidly developing bay
}

\author{
Ho Man Leung ${ }^{1} \cdot$ Kwai Chung Cheung ${ }^{2} \cdot$ Chi Kin $\mathrm{Au}^{3} \cdot$ Ken Kin Lam Yung ${ }^{1} \cdot$ Wai Chin $\mathrm{Li}^{4}$ \\ Received: 20 March 2020 / Accepted: 11 March 2021 / Published online: 17 March 2021 \\ (C) The Author(s), under exclusive licence to Springer-Verlag GmbH Germany, part of Springer Nature 2021
}

\begin{abstract}
The objective of this research is to investigate the pollution levels of tin ( $\mathrm{Sn}$ ), arsenic (As), cadmium (Cd), copper $(\mathrm{Cu})$, lead $(\mathrm{Pb})$, mercury ( $\mathrm{Hg}$ ), and zinc ( $\mathrm{Zn}$ ) of soil/sediment taken in Coles Bay Area (CBA), Svalbard, and Great Bay Area (GBA), China, in an attempt to evaluate the pollution potential related to recent development in the areas. A total of $150 \mathrm{soil} / \mathrm{sediment}$ samples were collected in each location. Heavy metal concentrations were detectable levels at all sites and the values of $\mathrm{Cd}$ of all soil/sediment samples were higher than Dutch Target and Intervention Values. Heavy metal concentration in soil/sediment was further analyzed by principal component analysis (PCA). It was revealed that three components were found in two studying sites and contributed $60.2 \%$ and $75.9 \%$ of variations to reflect soil/sediment quality in CBA and GBA, respectively. Based on the results of KMO $(0.52)$ and Bartlett's test $(p<0.000)$, there are $32.1 \%, 15.6 \%$, and $11.1 \%$ and $39.45 \%, 19.01 \%$, and $17.52 \%$ of the variance in the first, second, and third component explained that the metal concentration of $\mathrm{Pb}, \mathrm{Cd}$, and $\mathrm{Sn}$ was highly correlated with the soil/sediment quality in CBA and GBA, respectively. Among these three heavy metals, $\mathrm{Cd}$ concentration was the common dominant factor to affect soil/sediment quality in these two study sites. It is recommended that investigation of the sources of pollution (either point or non-point source) during CBA or GBA development and management together with consideration of abiotic (soil)-biotic (organisms) interactions should be taken into account when choosing suitable remediation strategies in the future.
\end{abstract}

Keywords Heavy metals · Principal component analysis (PCA) $\cdot$ Dutch Target and Intervention Values · Great Bay Area (GBA) . Coles Bay Area (CBA) · Svalbard

Responsible Editor: V. V.S.S. Sarma

Ken Kin Lam Yung

kklyung@hkbu.edu.hk

Wai Chin Li

waichin@eduhk.hk

1 Department of Biology, Hong Kong Baptist University, Hong Kong, China

2 Institute of Vocational Education, Hong Kong Vocational Training Council, Hong Kong, China

3 Department of History, Hong Kong Shue Yan University, Hong Kong, China

4 Department of Science and Environmental Studies, The Education University of Hong Kong, Hong Kong, China

\section{Introduction}

Estuaries are important nursery area for a juvenile marine organism such as crustaceans and fishes with less susceptible to predation (Sogard 1992; Potter et al. 2014) and provided main feeding areas for diadromous species due to steadily physio-chemical and osmoregulatory properties of estuaries area regulated by aquatic plants such as macrophytes. However, estuaries areas were heavily polluted by human activities such as land exploitation and reclamation, frequent agricultural activities, and tourism development recently. Thus, a large amount of inorganic toxic pollutants such as heavy metals are released from anthropogenic inputs (Ong 1995). Recently, due to increased population and industrial activities, coastal areas received industrial effluents such as heavy metal wastewater, petrol products in the smelting industry, and domestic sewage. As the heavy metals from toxic waste are binded to organic molecules and thus accumulating in both abiotic and biotic components naturally such as solid 
form (soil erosion, the remains of pesticides, and fertilizers), liquid form (leachates from surface runoff, water drainage), and gas form (waste gas deposition particulate matter emitted as ash and smog). The particles are thus depositing in coastal sediments (Storelli et al. 2001). Therefore, the surface sediment of estuaries areas could become heavily polluted with heavy metals.

The fluctuation of sediment properties in estuary areas and reactive heavy metals is present in water bodies and organisms (Zulkifli et al. 2010) due to the disturbance of chemical equilibrium of natural form of heavy metal by various pollutants and it was ready to bioaccumulate in organisms. Such bioavailable form of heavy metals concentration was transferred along with the food web and food chain in an ecosystem (Harikumar and Nasir 2010; Joksimovic et al. 2011). In order to conserve valuable natural resources of estuaries areas, evaluation of heavy metal in the areas is essential. The data can reflect sediment quality such as pollution states and degradation level nutrient cycle and understand the current states of actual/chronic effect on water pollution because it was well known that sediment can be regarded as important indicators for the sites (Atta and Xiao 2019; Allafta and Opp 2020; Kadhum 2020). Recent findings revealed that severe pollution was found in estuaries areas such as Nigeria (Tunde and Oluwagbenga 2020), Malaysia (Udechukwu et al. 2015), Brazil (Fonseca et al. 2020), New Zealand (Bastakoti et al. 2018), Atlantic Ocean (Bessa et al. 2020), Patagonia (Idaszkin et al. 2020), Egypt (Youssef et al. 2020), Italy (Arienzo et al. 2020), Bangladesh (Hossain 2019), and South Africa (Babatunde et al. 2015). Chen et al. (2010) found that an elevated concentration of Fe, $\mathrm{Mn}$, and $\mathrm{Zn}$ was found in Daya Bay, China, probably due to improper treatment of industrial effluent. On the other hand, van den Heuvel-Greve et al. (2016) detected organotin was present in sediment and suggested to continue monitoring contaminated levels in Coles Bay, Svalbard. Generally speaking, the degraded estuaries have common characteristics: deteriorated coastal vegetation, hardened shoreline, and sediment/ turbidity influx (Kennish 2012). Therefore, intense human activity such as land exploitation and tourism activities further reducing ecosystem goods and services. As both fauna and flora, biodiversity and complexity depend not only on the physical status of sediment such as temperature and salinity of water but also pollution level generally found in the estuary region. The sustainability of estuary habitat (i.e., freshwater with low salinity from river flow into marine habitat with high salinity) facilitates a huge amount of food availability to organisms such as the decay of plants and animals, organic debris, and dissolved particulate organic matters. Investigation of sediment quality can thus reflecting pollution status be disturbed by anthropogenic activities and it also acts as a basis to understand an indicator of water pollution in the estuary. However, there is scarce information on heavy metal pollution in newly developing areas in the year of 2019 such as Greater Bay Area (GBA) and Cole Bay Area (CBA). Henceforth, this study evaluates the heavy metal status of soil/sediment in CBA and GBA in an attempt to provide baseline information on soil management, namely to prescribe ameliorative measures in the form of physical manipulation.

\section{Materials and methods}

\section{Site description}

Cole Bay Area (Svalbard) was located in Svalbard where a location is a Norwegian group of islands in the Arctic Ocean north of continental Norway, about $650 \mathrm{mi}(1050 \mathrm{~km})$ from the North Pole (Fig. 1). It is the northernmost year-round settlement with a population of 2379 in the year 2019.

Greater Bay Area (China), including Dongguan (area: 2460 $\mathrm{km}^{2}$; population: 8,392,200), Foshan (area: $3798 \mathrm{~km}^{2}$; population: 7,906,000), Guangzhou (area: $7434 \mathrm{~km}^{2}$; population: 14,904,000), Hong Kong (area: $1107 \mathrm{~km}^{2}$; population: 7,486,400), Huizhou (area: $11,347 \mathrm{~km}^{2}$; population: 4830000), Jiangmen (area: $9507 \mathrm{~km}^{2}$; population: 4,598,200), Macao (area: $33 \mathrm{~km}^{2}$; population: 667,400), Shenzhen (area: $1997 \mathrm{~km}^{2}$; population:13,027,000), Zhaoqing (area: 14891 $\mathrm{km}^{2}$; population: 4,151,700), Zhongshan (area: $1784 \mathrm{~km}^{2}$; population: 3,310,000), Zhuhai (area: $1736 \mathrm{~km}^{2}$; population: $1,891,000)$, is an integration of agricultural, commercial, and industrial activities for newly develop economic zone in the region of the Pearl River Delta (Fig. 2).

\section{Sample collection and chemical analysis}

A total of 150 surface soil/sediment samples were collected in 2019 from two sites: Cole Bay Area and Greater Bay Area, and the sample locations were shown in Figs. 1 and 2. In order to understand the accumulation of heavy metal pollutants in sediment nearby coastal areas, samples were taken in the downstream of the river, and locations were recorded by using GPS (Table 1). Sampling was conducted according to the USEPA method (EPA 600, Mason 1992). All the samples were kept in an iced box transported to the laboratory and stored at $-20^{\circ} \mathrm{C}$ until further analysis.

Soil/sediment was homogenized and dried in the freeze drier for 10 days. Total metals in sediment samples including As (metalloid), $\mathrm{Cd}, \mathrm{Cr}, \mathrm{Hg}, \mathrm{Pb}, \mathrm{Sn}$, and $\mathrm{Zn}$ were extracted by HCl-HNO3-HF microwave digestion USEPA Standard Method 3051A (USEPA 2007a) and 3050B (USEPA 2007b). Standard reference material National Institute for Standards and Technology (NIST) 2711 Montana soil was used to verify the accuracy of metal determination, and the recovery percentage was $99.2 \%, 99.5 \%, 98.2 \%, 99.5 \%, 98.5 \%, 92.5 \%$, and $98.5 \%$ respectively. All of the digests were filtered through a $5 \mathrm{C}$ filter article and stored at $4{ }^{\circ} \mathrm{C}$. As, $\mathrm{Cd}, \mathrm{Cr}, \mathrm{Pb}, \mathrm{Sn}$, and $\mathrm{Zn}$ in extracts 


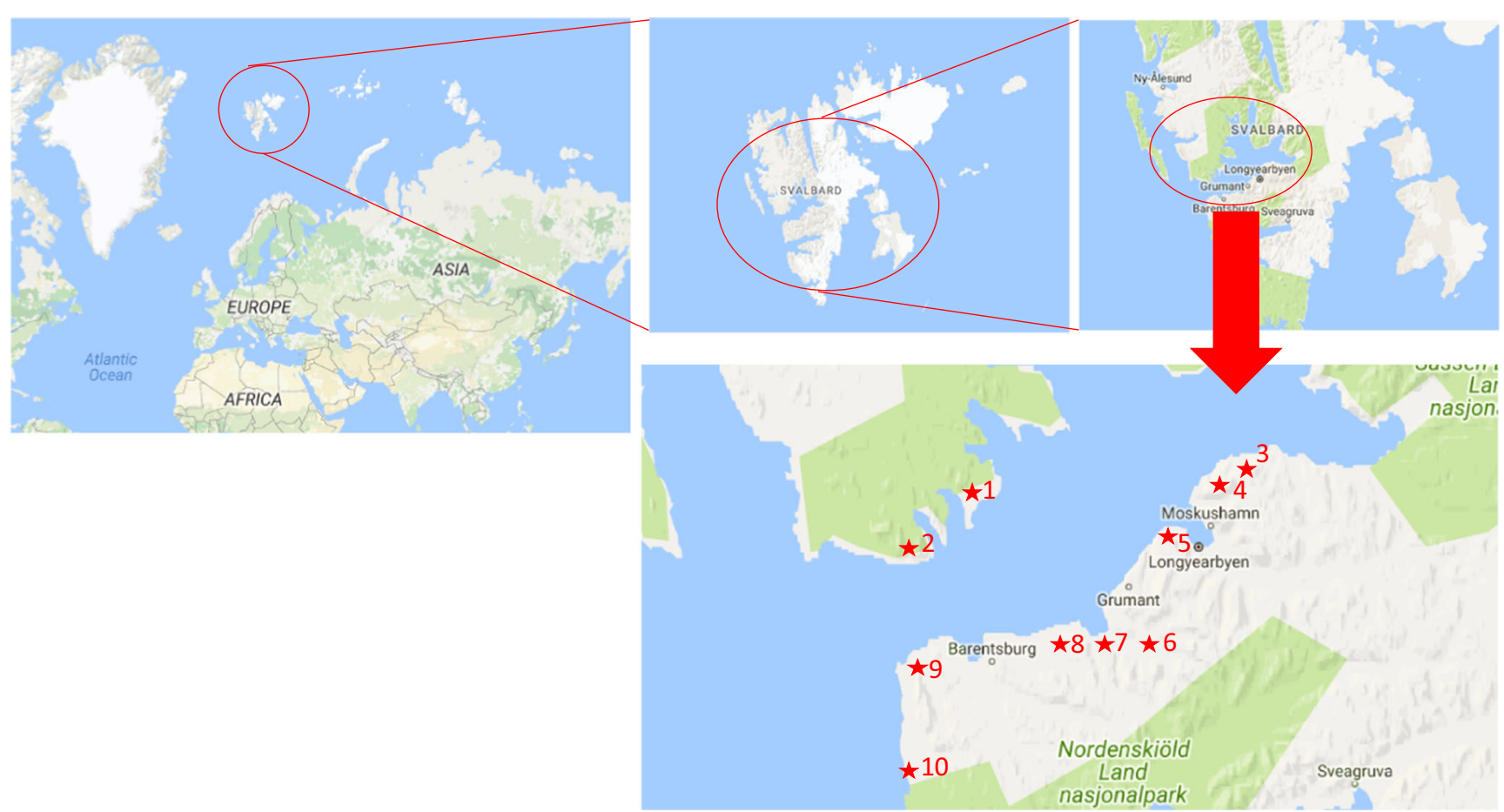

Fig. 1 Sampling locations in CBA, Svalbard

were determined by inductively coupled plasma optical emission spectrometry (Optima 3000 DV; Perkin Elmer) (USEPA 6010) (USEPA 2007c). A flow injection (Hg) system (FIAS400 Flow injection Mercury/Hydride System; Perkin Elmer) was used to measure total $\mathrm{Hg}$ in samples. Metal contents were expressed as milligram per kilogram.

\section{Principal component analysis (PCA) and statistical analysis}

Variable input for the PCA included heavy metal concentrations in soil/sediment samples. The data were assessed by Kaiser-Meyer-Olkin (KMO) statistics (value is $>0.5$ ), Bartlett's test (value is $<0.05$ ), eigenvalue (value is $>1.0$ ). Varimax - rotated - was applied to minimize the variations among the variables for each factor. All data were subjected to one-way ANOVA Duncan's multiple range test and $T$-test $(<0.05)$ using SPSS 16.0 software for further analysis. Means and standard derivation were calculated based on four replicates. Means were compared by Duncan's multiple range test.

\section{Results and discussion}

\section{General characteristics of heavy metal contamination in $\mathrm{CBA}$ and $\mathrm{GBA}$}

A summary of heavy metal of soil/sediment measured at each sampling location given in Tables 1 and 2. The range of total
$\mathrm{Sn}, \mathrm{As}, \mathrm{Cd}, \mathrm{Cu}, \mathrm{Pb}, \mathrm{Hg}$, and $\mathrm{Zn}$ (in $\mathrm{mg} / \mathrm{kg}$ ) in sediment samples taken in CBA and GBA were 1.41-3.01, 1.74-6.99, $1.19-3.50,1.63-9.40,16.3-188.4,1.17-5.26$, and $0.06-4.83$ and $1.41-46.88,1.74-34.0,1.19-9.23,14.1-382,23.3-538$, $0.005-0.312$, and $2.63-161$, respectively. All soil/sediment in two sites exhibited Cd contamination levels were higher than Dutch value (i.e., $0.8 \mathrm{mg} / \mathrm{kg}$ ) (VROM 2016). The current results revealed significantly higher $\mathrm{Cd}$ concentration found in all samples than the $\mathrm{Cd}$ concentration in the natural environment. Normally, heavy metals are present in the soil/sediment except it becomes contaminants in the environment. Due to human activities, heavy metal deposition in soil/sediment after refining and smelting is faster than the rate of metal generation by natural processes such as erosion and sedimentation (Wuana and Okieimen 2011, b); the possible pollutants include atmospheric deposition, smelting by-product, and inorganic minerals; and the losses by leaching and volatilization from tailings are thus accumulated in the bay areas. The mobile form of metal binded to the surface of natural materials and exposed directly to an environment and rendered in the habitat.

Interestingly, it was found that the variation of soil/sediment structure and a different topography in two sites leads to varying heavy metal concentrations in soil/sediment. In CBA, the major component of soil/sediment is cold desert soil formed from quick temperature fluctuation and weathering. On the other hand, in GBA, fertile soil/sediment was deteriorated by heavy urban activities resulting in erosion and soil/sediment compaction. Consequently, the loss of 


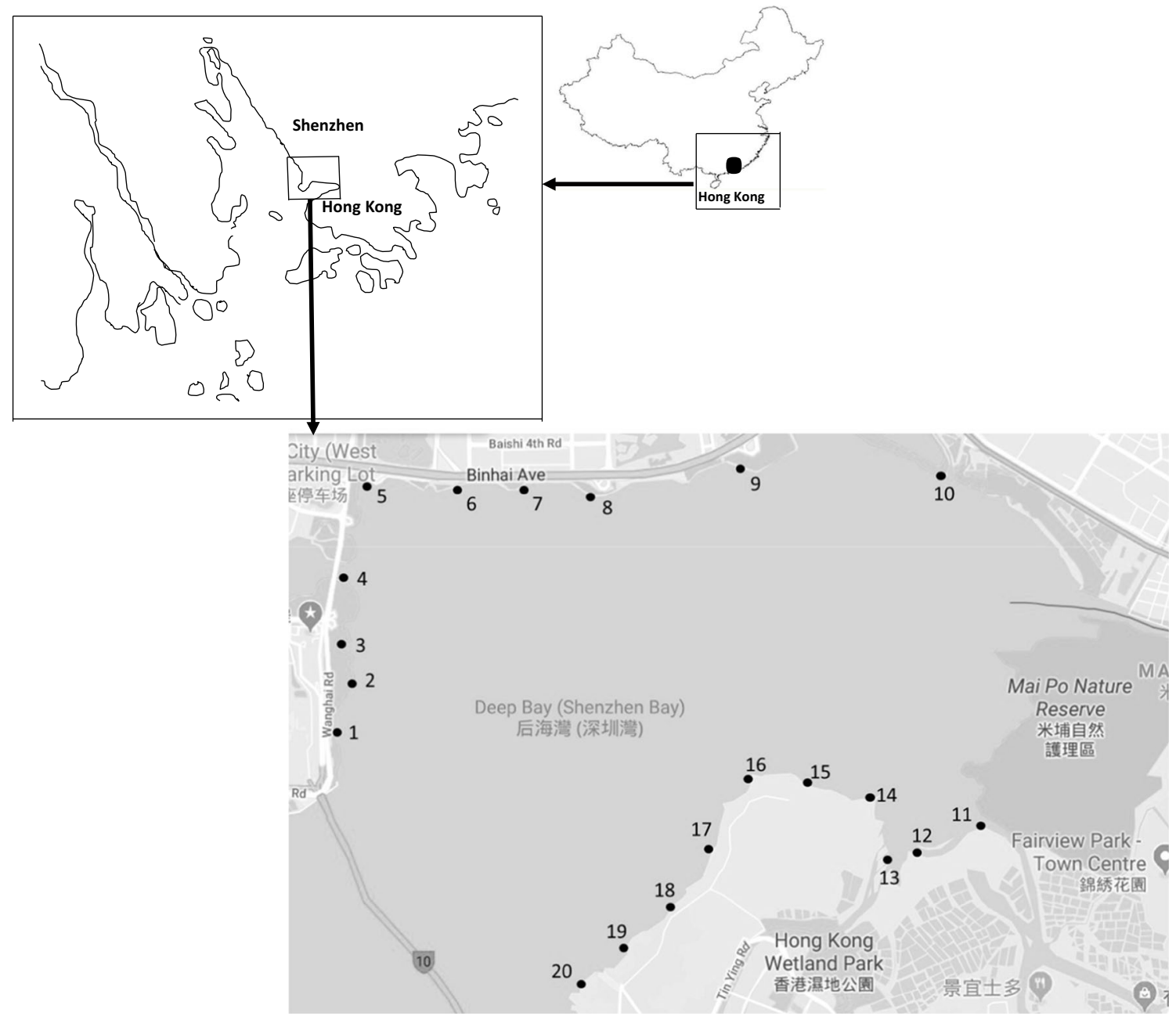

Fig. 2 Sampling locations in GBA, China

colloidal particles of soil organic matter in the sediment leads to the imbalance between sorption and leaching of soil/sediment lead to altering the available adsorptive surfaces to bind heavy metals (Thonon 2006). Hence, there were varied metal contaminations in the soil/sediment between distinctly different locations.

Table 1 Heavy metal concentration of soil/sediment in CBA ( $n=5$, total 50 samples). Highlighted values indicated the concentration exceeds Dutch target and intervention values

\begin{tabular}{|c|c|c|c|c|c|c|c|c|c|}
\hline \multirow[t]{2}{*}{ Location } & \multicolumn{2}{|c|}{ GPS reading } & \multicolumn{7}{|c|}{ Heavy metal concentration ( $\mathrm{mg} / \mathrm{kg}$, dry weight)* } \\
\hline & GPS (North) & GPS (East) & Sn & As & $\mathrm{Cd}$ & $\mathrm{Cu}$ & $\mathrm{Pb}$ & $\mathrm{Hg}$ & $\mathrm{Zn}$ \\
\hline 1 & 78.284623 & 14.048613 & $3.36 \pm 0.28 \mathrm{a}$ & $3.32 \pm 0.21 \mathrm{ab}$ & $1.82 \pm 0.14 \mathrm{~b}$ & $3.66 \pm 0.41 \mathrm{~b}$ & $26.9 \pm 12.3 \mathrm{e}$ & $2.81 \pm 0.22 \mathrm{~b}$ & $1.80 \pm 0.26 \mathrm{a}$ \\
\hline 2 & 78.210779 & 13.762969 & $3.17 \pm 0.94 \mathrm{a}$ & $2.92 \pm 0.89 b$ & $1.74 \pm 0.35 b$ & $3.39 \pm 1.06 \mathrm{~b}$ & $36.3 \pm 11.3 \mathrm{~d}$ & $2.55 \pm 0.51 b$ & $1.82 \pm 0.28 \mathrm{a}$ \\
\hline 3 & 78.242162 & 15.471343 & $2.92 \pm 0.24 \mathrm{a}$ & $4.52 \pm 0.29 \mathrm{ab}$ & $2.87 \pm 0.23 \mathrm{a}$ & $6.85 \pm 0.78 \mathrm{a}$ & $54.7 \pm 25.1 \mathrm{c}$ & $4.33 \pm 0.34 a$ & $2.25 \pm 0.33 a$ \\
\hline 4 & 78.233204 & 15.383452 & $2.75 \pm 0.82 \mathrm{ab}$ & $3.97 \pm 1.21 \mathrm{ab}$ & $2.75 \pm 0.56 a$ & $6.33 \pm 1.99 \mathrm{a}$ & $73.7 \pm 23.0 \mathrm{~b}$ & $3.93 \pm 0.79 b$ & $2.29 \pm 0.35 \mathrm{a}$ \\
\hline 5 & 78.239923 & 15.460356 & $1.58 \pm 0.13 \mathrm{ab}$ & $5.43 \pm 0.35 \mathrm{a}$ & $2.50 \pm 0.20 \mathrm{a}$ & $6.71 \pm 0.76 a$ & $63.7 \pm 25.6 b c$ & $3.76 \pm 0.30 \mathrm{~b}$ & $2.44 \pm 0.36 \mathrm{a}$ \\
\hline 6 & 78.120655 & 15.103301 & $1.49 \pm 0.44 \mathrm{ab}$ & $4.77 \pm 1.45 \mathrm{a}$ & $2.39 \pm 0.48 \mathrm{a}$ & $6.21 \pm 1.95 \mathrm{a}$ & $131.3 \pm 26.9 \mathrm{a}$ & $3.41 \pm 0.69 \mathrm{~b}$ & $2.41 \pm 0.32 \mathrm{a}$ \\
\hline 7 & 78.088952 & 14.971465 & $0.17 \pm 3.86 \mathrm{~d}$ & $5.59 \pm 0.36 \mathrm{a}$ & $3.03 \pm 0.24 a$ & $8.12 \pm 0.92 \mathrm{a}$ & $56.2 \pm 14.8 \mathrm{c}$ & $3.27 \pm 0.26 \mathrm{~b}$ & $2.11 \pm 0.31 \mathrm{a}$ \\
\hline 8 & 78.093486 & 14.823149 & $0.81 \pm 5.92 \mathrm{c}$ & $4.91 \pm 1.49 a$ & $2.90 \pm 0.59 \mathrm{a}$ & $7.51 \pm 2.36 \mathrm{a}$ & $169.7 \pm 16.3 \mathrm{a}$ & $2.97 \pm 0.60 \mathrm{~b}$ & $2.12 \pm 0.33 \mathrm{a}$ \\
\hline 9 & 78.088952 & 13.916777 & $0.08 \pm 0.007 \mathrm{e}$ & $5.42 \pm 0.35 \mathrm{a}$ & $2.51 \pm 0.20 \mathrm{a}$ & $6.01 \pm 0.68 \mathrm{a}$ & $71.6 \pm 3.86 \mathrm{~b}$ & $1.47 \pm 0.12 \mathrm{c}$ & $1.94 \pm 0.30 \mathrm{a}$ \\
\hline 10 & 78.050343 & 13.680571 & $0.08 \pm 0.024 \mathrm{e}$ & $4.77 \pm 1.45 \mathrm{a}$ & $2.40 \pm 0.49 \mathrm{a}$ & $5.56 \pm 1.74 \mathrm{a}$ & $81.4 \pm 5.92 b$ & $1.33 \pm 0.27 \mathrm{c}$ & $1.96 \pm 0.29 \mathrm{a}$ \\
\hline & & $\mathrm{OM}, 20$ & 19.0 & 29.0 & 0.80 & 36.0 & 85.0 & 0.30 & 140.0 \\
\hline
\end{tabular}

*Within each location, means with the same letter are not significantly different according to Duncan's multiple range test at 5\% level. The bolded data indicated the concentration was higher than Dutch Target and Intervention Values (VROM 2016) 
Table 2 Heavy metal concentration of soil/sediment in GBA ( $n=5$, total 100 samples). Highlighted values indicated the concentration exceeds Dutch target and intervention values

\begin{tabular}{|c|c|c|c|c|c|c|c|c|c|}
\hline \multirow[t]{2}{*}{ Location } & \multicolumn{2}{|c|}{ GPS reading } & \multicolumn{7}{|c|}{ Heavy metal concentration $(\mathrm{mg} / \mathrm{kg}$, dry weight)* } \\
\hline & GPS (North) & GPS (East) & $\mathrm{Sn}$ & As & $\mathrm{Cd}$ & $\mathrm{Cu}$ & $\mathrm{Pb}$ & $\mathrm{Hg}$ & $\mathrm{Zn}$ \\
\hline 1 & 22.493577 & 113.952181 & $1.78 \pm 0.03 \mathrm{c}$ & $8.23 \pm 0.04 \mathrm{~b}$ & $3.61 \pm 0.08 \mathrm{c}$ & $123 \pm 0.15 b$ & $59.2 \pm 1.86 \mathrm{c}$ & $0.034 \pm 0.05 \mathrm{c}$ & $30.4 \pm 1.22 \mathrm{~d}$ \\
\hline 2 & 22.492288 & 113.954239 & $1.83 \pm 0.09 \mathrm{c}$ & $34.0 \pm 0.02 \mathrm{a}$ & $1.89 \pm 0.04 \mathrm{~d}$ & $327 \pm 0.12 \mathrm{a}$ & $163.7 \pm 1.73 b$ & $0.044 \pm 0.07 \mathrm{c}$ & $34.0 \pm 1.66 \mathrm{~d}$ \\
\hline 3 & 22.504838 & 113.953393 & $1.41 \pm 0.06 \mathrm{c}$ & $3.64 \pm 1.05 \mathrm{~d}$ & $1.71 \pm 0.17 \mathrm{~d}$ & $382 \pm 0.15 \mathrm{a}$ & $164.3 \pm 2.11 \mathrm{~b}$ & $0.015 \pm 0.04 \mathrm{c}$ & $32.7 \pm 1.88 \mathrm{~d}$ \\
\hline 4 & 22.509121 & 113.953034 & $5.01 \pm 0.04 \mathrm{~b}$ & $3.06 \pm 0.14 \mathrm{~d}$ & $1.63 \pm 0.39 \mathrm{~d}$ & $21.8 \pm 0.61 \mathrm{de}$ & $381.3 \pm 1.80 \mathrm{a}$ & $0.016 \pm 0.08 \mathrm{c}$ & $38.1 \pm 2.85 \mathrm{~d}$ \\
\hline 5 & 22.511341 & 113.952690 & $8.88 \pm 0.03 b$ & $3.32 \pm 0.18 \mathrm{~d}$ & $1.99 \pm 0.15 \mathrm{~d}$ & $52.9 \pm 0.71 d$ & $215.7 \pm 3.60 \mathrm{ab}$ & $0.022 \pm 0.02 \mathrm{c}$ & $119.2 \pm 0.45 b$ \\
\hline 6 & 22.519415 & 113.959311 & $3.82 \pm 0.43 \mathrm{bc}$ & $9.79 \pm 0.03 \mathrm{a}$ & $1.94 \pm 0.14 \mathrm{~d}$ & $68.2 \pm 0.31 \mathrm{c}$ & $417.1 \pm 4.60 \mathrm{a}$ & $0.059 \pm 0.09 \mathrm{c}$ & $106.1 \pm 0.93 b$ \\
\hline 7 & 22.519941 & 113.987124 & $1.53 \pm 0.02 \mathrm{c}$ & $5.59 \pm 0.26 b$ & $3.99 \pm 0.08 \mathrm{c}$ & $20.6 \pm 0.28 \mathrm{de}$ & $44.6 \pm 1.65 \mathrm{~cd}$ & $0.117 \pm 0.03 b$ & $99.4 \pm 0.13 b$ \\
\hline 8 & 22.520368 & 113.999486 & $1.91 \pm 0.09 \mathrm{c}$ & $11.7 \pm 0.06 \mathrm{a}$ & $1.19 \pm 0.16 \mathrm{~d}$ & $42.4 \pm 0.13 \mathrm{~d}$ & $23.3 \pm 2.91 \mathrm{~d}$ & $0.005 \pm 0.02 \mathrm{c}$ & $48.3 \pm 1.95 \mathrm{~d}$ \\
\hline 9 & 22.524015 & 114.009960 & $1.83 \pm 0.01 \mathrm{c}$ & $6.81 \pm 0.07 b$ & $2.11 \pm 0.10 \mathrm{~b}$ & $34.5 \pm 0.14 d$ & $24.7 \pm 1.25 \mathrm{~d}$ & $0.007 \pm 0.01 \mathrm{c}$ & $27.6 \pm 2.36 \mathrm{~d}$ \\
\hline 10 & 22.519731 & 114.019574 & $2.25 \pm 0.08 \mathrm{c}$ & $6.43 \pm 0.05 b$ & $1.62 \pm 0.10 \mathrm{~d}$ & $45.9 \pm 0.17 \mathrm{~d}$ & $47.1 \pm 1.43 c \mathrm{c}$ & $0.139 \pm 0.07 \mathrm{~b}$ & $25.8 \pm 1.38 \mathrm{~d}$ \\
\hline $\begin{array}{l}11 \\
12\end{array}$ & $\begin{array}{l}22.483569 \\
22.481350\end{array}$ & $\begin{array}{l}114.024714 \\
114.019564\end{array}$ & $\begin{array}{l}2.12 \pm 0.24 c \\
15.1 \pm 0.39 b\end{array}$ & $\begin{array}{l}6.76 \pm 0.02 b \\
5.78 \pm 0.09 b\end{array}$ & $\begin{array}{l}1.66 \pm 0.05 d \\
1.63 \pm 0.16 b\end{array}$ & $\begin{array}{l}65.0 \pm 0.36 c \\
63.1 \pm 0.53 c\end{array}$ & $\begin{array}{l}142 \pm 6.30 b \\
175 \pm 3.66 b\end{array}$ & $\begin{array}{l}0.257 \pm 0.04 \mathrm{ab} \\
0.176 \pm 0.02 \mathrm{~b}\end{array}$ & $\begin{array}{l}161 \pm 0.52 \mathrm{a} \\
69.6 \pm 0.96 \mathrm{c}\end{array}$ \\
\hline 13 & 22.479924 & 114.014243 & $5.27 \pm 0.08 \mathrm{bc}$ & $4.16 \pm 0.04 b c$ & $9.23 \pm 0.26 a$ & $41.8 \pm 0.51 d$ & $106 \pm 1.37 b c$ & $0.166 \pm 0.04 b$ & $115 \pm 0.23 \mathrm{a}$ \\
\hline 14 & 22.480744 & 114.012356 & $2.14 \pm 0.04 \mathrm{c}$ & $1.74 \pm 0.13 \mathrm{~d}$ & $1.89 \pm 0.13 \mathrm{~b}$ & $70.7 \pm 0.55 \mathrm{c}$ & $175 \pm 3.67 b$ & $0.312 \pm 0.07 \mathrm{a}$ & $55.9 \pm 0.86 \mathrm{~d}$ \\
\hline 15 & 22.488807 & 114.003774 & $1.95 \pm 0.02 b$ & $2.51 \pm 0.12 \mathrm{~d}$ & $4.27 \pm 0.07 b$ & $29.7 \pm 0.22 \mathrm{de}$ & $101 \pm 2.80 \mathrm{bc}$ & $0.158 \pm 0.06 b$ & $57.6 \pm 0.33 \mathrm{~d}$ \\
\hline 16 & 22.486429 & 113.995191 & $1.61 \pm 0.07 b$ & $3.18 \pm 0.14 \mathrm{~d}$ & $4.11 \pm 0.24 \mathrm{~b}$ & $14.1 \pm 0.45 \mathrm{f}$ & $538 \pm 4.50 \mathrm{a}$ & $0.027 \pm 0.09 \mathrm{c}$ & $3.31 \pm 1.75 \mathrm{a}$ \\
\hline 17 & 22.486429 & 113.993991 & $11.14 \pm 0.57$ & $3.04 \pm 0.15 \mathrm{~d}$ & $5.78 \pm 0.13 b$ & $36.8 \pm 0.50 \mathrm{e}$ & $424 \pm 8.65 \mathrm{a}$ & $0.122 \pm 0.04 b$ & $3.06 \pm 1.47 \mathrm{a}$ \\
\hline 18 & 22.474533 & 113.998669 & $46.88 \pm 0.08 \mathrm{a}$ & $4.16 \pm 0.04 b c$ & $1.86 \pm 0.10 \mathrm{~b}$ & $35.5 \pm 0.17 \mathrm{e}$ & $172 \pm 3.03 b$ & $0.135 \pm 0.09 b$ & $2.63 \pm 0.06 b$ \\
\hline 19 & 22.469288 & 113.982146 & $12.35 \pm 0.81 b$ & $1.74 \pm 0.13 \mathrm{~d}$ & $2.85 \pm 0.07 \mathrm{~d}$ & $43.1 \pm 0.16 \mathrm{~d}$ & $67.7 \pm 1.05 \mathrm{c}$ & $0.156 \pm 0.03 b$ & $49.0 \pm 0.318 d$ \\
\hline 20 & 22.458195 & 113.975796 & $34.58 \pm 0.92 \mathrm{a}$ & $7.13 \pm 0.06 b$ & $4.82 \pm 0.04 b$ & $26.1 \pm 0.05 \mathrm{e}$ & $84.1 \pm 2.45 b c$ & $0.128 \pm 0.05 b$ & $155 \pm 0.874 a$ \\
\hline . & . & varues, & 19.0 & 29.0 & 0.80 & 36.0 & 85.0 & 0.30 & 140.0 \\
\hline
\end{tabular}

2000 (the New Dutch List) (VROM, 2016)

*Within each location, means with the same letter are not significantly different according to Duncan's multiple range test at 5\% level. The bolded data indicated the concentration was higher than Dutch Target and Intervention Values (VROM 2016)

Further analysis was conducted by PCA. The PCA is performed at each site on the heavy metal content of soil/sediment. The percent of variance (heavy metal concentrations) by all studying sites is presented in Figs. 3 and 4 . The result exhibited the soil/sediment with similar properties was closer to each other and vice versa. It was revealed that three components were found in two studying sites and contributed $60.2 \%$ and $75.9 \%$ of variations to reflect soil/sediment quality in CBA and GBA, respectively. Based on the results of KMO $(0.52)$ and Bartlett's test $(p<0.000)$, there are $32.1 \%, 15.6 \%$,

Table 3 Rotated component matrix for soil/sediment samples taken in CBA

\begin{tabular}{lccc}
\hline \multirow{2}{*}{ Component } & \multicolumn{2}{l}{ Eigenvalues } & \\
\cline { 2 - 4 } & 1 & 2 & 3 \\
\hline $\mathrm{Sn}$ & -0.152 & -0.189 & -0.637 \\
$\mathrm{As}$ & -0.339 & -0.238 & -0.169 \\
$\mathrm{Cd}$ & 0.435 & 0.162 & 0.747 \\
$\mathrm{Cu}$ & -0.433 & -0.891 & -0.167 \\
$\mathrm{~Pb}$ & 0.162 & 0.211 & -0.418 \\
$\mathrm{Hg}$ & -0.144 & -0.016 & -0.294 \\
$\mathrm{Zn}$ & 0.784 & -0.566 & -0.128 \\
Eigenvalue & 1.73 & 1.38 & 1.61 \\
$\mathrm{Contribution}$ & 32.1 & 15.6 & 11.1 \\
\hline
\end{tabular}

and $11.1 \%$ and $39.45 \%, 19.01 \%$, and $17.52 \%$ of the variance in the first, second, and third component explained the metal concentration of $\mathrm{Pb}, \mathrm{Cd}$, and $\mathrm{Sn}$ were highly correlated with the soil/sediment quality in CBA and GBA, respectively (Tables 3 and 4).

By comparing the concentration of pollutants of sediment in CBA and GBA, the source of pollutants may be attributed to the various industrial activities in $\mathrm{CBA}$ and GBA. According to the study of Najamuddin et al. (2016), the possible explanation was among different forms of heavy metal in

Table 4 Rotated component matrix for soil/sediment samples taken in GBA

\begin{tabular}{lccc}
\hline Component & \multicolumn{2}{l}{ Eigenvalues } & \\
\cline { 2 - 4 } & 1 & 2 & 3 \\
\hline $\mathrm{Sn}$ & -0.123 & -0.213 & -0.181 \\
$\mathrm{As}$ & -0.124 & -0.145 & -0.185 \\
$\mathrm{Cd}$ & 0.154 & 0.114 & 0.125 \\
$\mathrm{Cu}$ & -0.133 & -0.111 & -0.014 \\
$\mathrm{~Pb}$ & -0.107 & 0.087 & -0.109 \\
$\mathrm{Hg}$ & -0.158 & -0.185 & -0.200 \\
$\mathrm{Zn}$ & -0.441 & -0.256 & -0.282 \\
Eigenvalue & 1.08 & 1.25 & 1.90 \\
Contribution & 39.45 & 19.01 & 17.52 \\
\hline
\end{tabular}


Fig. 3 PCA analysis of soil/sediment samples taken in CBA $(n=5,50$ samples in total) (index: $\mathrm{V}=$ sample sites)

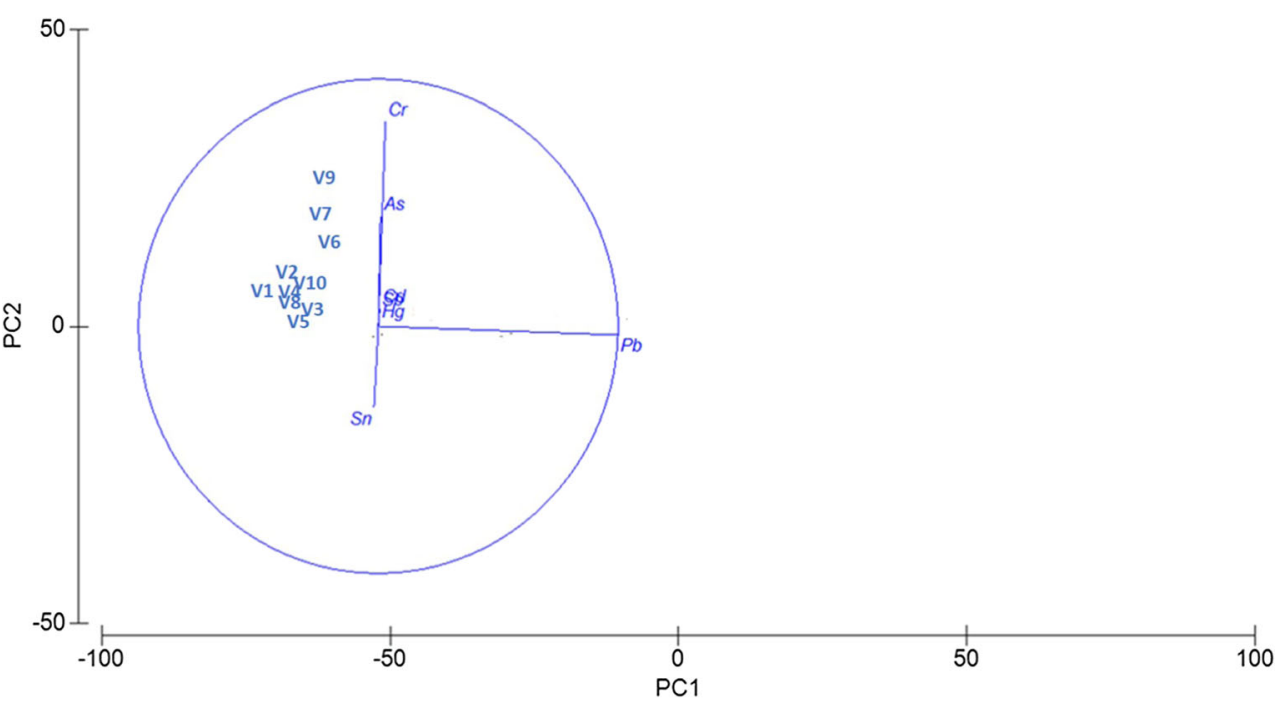

sediment such as carbonated reducible, oxidizable, exchangeable, and residual; exchangeable forms of metal can be acquired by marine organisms with the integration of suitable physical environment found in GBA such as turbidity, salinity, acidity, and alkalinity. The oxidizable, reducible, and carbonate forms of heavy metal transformed readily into exchangeable forms (Ma et al. 2016). Additionally, due to the intensive agricultural activities, a large amount of water or effluent with high organic matter component was discharged into the estuary and heavy metal binded to these organic matters gradually. As the organometallic compounds are biopersistent in nature henceforth once assimilated by an organism, it remains persistence for many years (Wuana and Okieimen 2011, b). As a result, heavy metals may bind to an active site of alkaline phosphatase commonly present in biotic and thus metabolism is disrupted (McGrath 1999). In addition, the function of mitochondria interfered in the basophilic cells of the hepatopancreas due to heavy metal reacts with membranes, and this may be the biochemical basis for toxic effects on mitochondria (Vallee and Ulmer 1972)

\section{Relationship between heavy metal contamination in soil/sediment and unique weather condition in CBA}

There are two out of ten locations that exceed the guideline for $\mathrm{Cd}, \mathrm{Pb}$, and $\mathrm{Hg}$ concentration in $\mathrm{CBA}$ where the sampling locations are close to shipyards and coal-fire electric power stations in sites 6 and 8. Transport emission and increased electric consumption by visitors contributed unusual chemical composition of the sediment. Cd in soil/sediment may be comprised from the geological parent material and extraneous sources such as the long-distance transport of Cd by air current (Weinbruch et al. 2012), atmospheric deposition, and water from melting snow and glaciers due to global warming are the possible sources of metal deposited in soil/sediment (Samecka-Cymerman et al. 2011; Ruman et al. 2012;
Fig. 4 PCA analysis of soil/sediment samples taken in GBA ( $n=5,100$ samples in total) (index: $\mathrm{V}=$ sample sites)

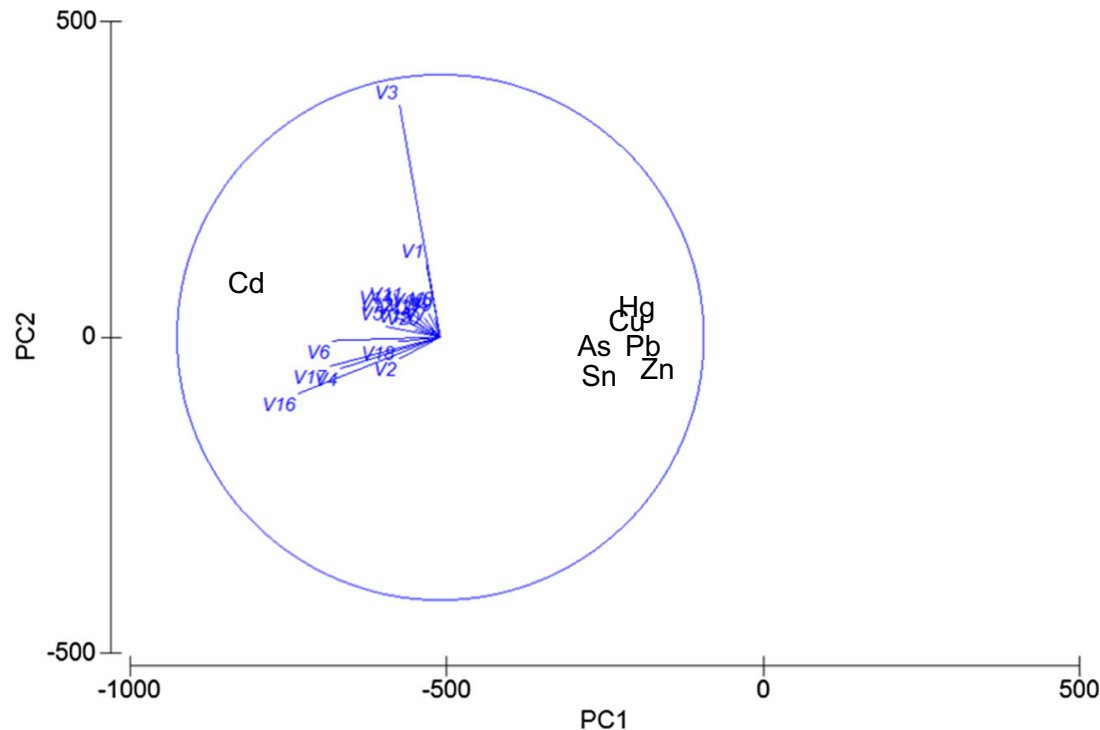


Weinbruch et al. 2012). The elevated Cd concentration found in soil/sediment may be subjected to large scale of such heavy metal emitted from the pollutant sources. On the other hand, the coal residue from the coal-fire power station and fly ash and particulate matter emitted from the chimney contained a high percentage of organic matter (as the original source of coal is plant residue) and could aid to bind heavy metal on sediment/soil. An extreme temperature changed during day and night in CBA leads to form aerosol, dust, fog, haze, fume, smog, smoke, soot, and particulate matter readily, and the findings were in line with Agrawal and Pottsmith (2000). Such toxicants were distributed pervasively and caused human health hazards including acute and chronic metal toxicity.

Furthermore, materials generated from coal-fired electric power stations included solid (coal residue), liquid (warm water), and gas (flue gas) and lead to land pollution (improper treatment of tailings, coal ash, overburden, and waste rocks), thermal pollution (degradation of water quality that change in an ambient temperature), and air pollution (such as nitrogen dioxide, sulfur dioxide, ammonium compounds which are dissolved in suspended water vapor to create acidic smog), and such pollutants further deposited into soil/sediment, producer and consumer in the tropical level of an ecosystem. Therefore, respective pollutants were accumulated into abiotic and biotic components in the natural environment and deteriorated environmental quality in CBA.

\section{The impact of unlimited urban development on sediment/soil quality in GBA}

The GBA region is under an ever-increasing anthropogenic impact, including local industrial center, reclamation, and alteration of coastal line and hence change of flowing water and sedimentary material in Pearl River Delta (PRD). Especially, four out of seven contaminants exceeded the guideline where the pollution sources are probably from illegal wastewater discharged from textile factories in sites 2 and 14. As the GBA is nearby the Pearl River Delta (well-known industrial area reported by Wan et al. (2020); Lu et al. (2020); Zhang et al. (2017)), the riverine system is suffering from various pollution by intense human activities. Heavy metals are thus depositing in sediment and cause enrichment. Recently, GBA experienced a reclamation project ti cope with economic growth and industrialization planned by the government after the COVID-19 pandemic. Anthropogenic activities resulting from the rapid development of commercial areas, industrial zone, coal-generation plants, transport, coal-fired power station, transportation pub, livestock, and agricultural activities make the main source contaminants in GBA. The soil/sediment in the seabed of the reclaimed land becomes anoxic and converted into oxidized conditions. Thus, the stable organic bound-heavy metal released into the water and entered into the sediment (Chen and Jiao 2008). The anthropogenic impact leads to the degradation of marine ecology as well as food chains, contributing to a rapid transport of toxicants to final consumers through bioaccumulation and biomagnification.

\section{Conclusion}

The results from the current study revealed that sediment in CBA and GBA was heavily contaminated with heavy metals such as $\mathrm{Cd} / \mathrm{Pb} / \mathrm{Sn}$ according to PCA results. A significantly higher concentration of these heavy metals was found in sediments due to various anthropogenic activities in different locations. Besides, the availability of toxic metals appears to be elevated in the studying sites as the nature of the soil compositions altered substantially by natural and human activities, thus posing short- and long-term impacts to an ecosystem. Implementation of various strategies to mitigate heavy metal contamination is necessary to restore the bay areas such as frequent monitoring the anthropogenic activities especially in mining and smelting activities, microbial remediation of contaminated soil/sediment (Ayangbenro and Babalola 2017), modeling the future trend of heavy metal loading in soil/sediment, and reduce metal bioavailability to the biotic such as liming or addition of biochar to the soil/sediment (Bian et al. 2013, 2014). As an intense human activity found in both areas, it is necessary to increase transparency by improving and updating information on different heavy metal concentrations in order to establish a framework for proper management and control by authorities. Besides, investigation of the sources of pollution (either point or non-point source) during CBA or GBA development and management together with consideration of abiotic (soil)-biotic (organisms) interactions should be taken into account when choosing suitable remediation strategies in the future.

Acknowledgements Special thanks to Mr. Chan TH and Ms. Ella Wightman to improve fluent in the written English of the manuscript.

Availability of data and materials The datasets used and/or analyzed during the current study are available from the corresponding author on reasonable request.

Author contributions Ho Man Leung analyzed the data and was a major contributor in writing the manuscript.

Kwai Chung Cheung provided guidance on statistical analysis.

$\mathrm{Chi} \mathrm{Kin} \mathrm{Au}$ provided interpretation to the data.

Ken Kin Lam Yung organized the plan of research.

Wai Chin Li organized the plan of research.

\section{Declarations}

Ethics approval and consent to participate Not applicable. 
Consent for publication Not applicable.

Competing interests The authors declare no competing interests.

\section{References}

Agrawal YC, Pottsmith HC (2000) Instruments for particle size and settling velocity observations in sediment transport. Mar Geol 168:89114

Allafta H, Opp C (2020) Spatio-temporal variability and pollution sources identification of the surface sediments of Shatt Al-Arab River, Southern Iraq. Sci Rep 10:6979

Arienzo M, Bolinesi F, Aiello G, Barra D, Donadio C, Stanislao C, Ferrara L, Mangoni O, Toscanesi M, Giarra A, Trifuoggi M (2020) The environmental assessment of an estuarine transitional environment, southern Italy. J Mar Sci Eng 8:628

Atta R, Xiao T (2019) Distribution and potential ecological risk assessment of trace elements in the stream water and sediments from Lanmuchang area, southwest Guizhou, China. Environ Sci Pollut Res Int 26:3706-3722

Ayangbenro SA, Babalola OO (2017) A new strategy for heavy metal polluted environments: a review of microbial biosorbents. Int J Environ Res Public Health 14:94

Babatunde BB, Sikoki FD, Hart I (2015) Human health impact of natural and artificial radioactivity levels in the sediments and fish of Bonny Estuary, Niger Delta. Challenges 6:244-257

Bastakoti U, Robertson J, Alfaro AC (2018) Spatial variation of heavy metals in sediments within a temperate mangrove ecosystem in northern New Zealand. Mar Pollut Bull 135:790-800

Bessa AZE, Ngueutchoua G, Janpou AK, El-Amier YA, Nguetnga OANNM, Kayou URK, Bisse SB, Mapuna ECN, ArmstrongAltrin JS (2020) Heavy metal contamination and its ecological risks in the beach sediments along the Atlantic Ocean (Limbe coastal fringes, Cameroon). Earth Syst Environ. https://doi.org/10.1007/ s41748-020-00167-5

Bian RJ, Chen D, Liu XY, Cui LQ, Li LQ, Pan GX, Xie D, Zheng JW, Zhang XH, Zheng JF, Chang A (2013) Biochar soil amendment as a solution to prevent Cd-tainted rice from China: results from a crosssite field experiment. Ecol Eng 58:378-383

Bian RJ, Joseph S, Cui L, Pan G, Li L, Liu X, Zhang A, Rutlidge H, Wong S, Chia C, Marjo C, Gong B, Munroe P, Donne S (2014) A three-year experiment confirms continuous immobilization of cadmium and lead in contaminated paddy field with biochar amendment. J Hazard Mater 272:121-128

Chen K, Jiao JJ (2008) Metal concentrations and mobility in marine sediment and groundwater in coastal reclamation areas: a case study in Shenzhen, China. Environ Pollut 151:576-584. https://doi.org/ 10.1016/j.envpol.2007.04.004

Chen TR, Yu KF, Li S, Price GJ, Shi Q, Wei G (2010) Heavy metal pollution recorded in Porites corals from Daya Bay, northern South China Sea. Mar Environ Res 70:318-326

Fonseca EM, Fernandes JR, Lima LS, Delgado J, Correa TR, Costa PMS, Neto JAB, Aguiar VMC (2020) Effects of dredged sediment dumping on trace metals concentrations and macro benthic assemblage at the continental shelf adjacent to a tropical urbanized estuary. Ocean Coast Manag 196:105299

Harikumar P, Nasir U (2010) Ecotoxicological impact assessment of heavy metals in core sediments of a tropical estuary. Ecotoxicol Environ Saf 73:1742-1747

Hossain HMZ (2019) Major, trace, and REE geochemistry of the Meghna River sediments, Bangladesh: constraints on weathering and provenance. Geol J 55:3321-3343. https://doi.org/10.1002/gj.3595
Idaszkin YL, Carol ES, Barcia-Piedras JM, Bouza PJ, Mateos-Naranjo E (2020) Trace metal concentrations in soil-plant complex in rocky shore salt marshes of Central Patagonia. Cont Shelf Res 211:104280

Joksimovic D, Tomic I, Stankovic AR, Jovic M, Stankovic S (2011) Trace metal concentrations in Mediterranean blue mussel and surface sediments and evaluation of the mussels quality and possible risks of high human consumption. Food Chem 127:632-637

Kadhum AS (2020) A preliminary study of heavy metals pollution in the sandy dust storms and its human risk assessment from middle and south of Iraq. Environ Sci Pollut Res 27:8570-8579. https://doi.org/ 10.1007/s11356-019-07380-4

Kennish MJ (2012) Restoration of Estuaries. Nat Educ Knowl 3:5

Lu Q, Bai J, Zhang G, Wu J (2020) Effects of coastal reclamation history on heavy metals in different types of wetland soils in the Pearl River Delta: levels, sources and ecological risks. J Clean Prod 272:122668

Ma X, Zuo H, Tian MJ, Zhang LY, Meng J, Zhou XN, Min N, Chang XY, Liu Y (2016) Assessment of heavy metals contamination in sediments from three adjacent regions of the Yellow River using metal chemical fractions and multivariate analysis techniques. Chemosphere 144:264-272

Mason B (1992) Preparation of soil sampling protocols: sampling techniques and strategies. U.S, Environmental Protection Agency, Washington, D.C.

McGrath SP (1999) Adverse effects of cadmium on soil microflora and fauna. In: Cadmium in soils and plants, pp 199-218

Najamuddin PT, Sanusi HS, Nurjaya IW (2016) Seasonal distribution and geochemical fractionation of heavy metals from surface sediment in a tropical estuary of Jeneberang River, Indonesia. Mar Pollut Bull 111:456-462

Ong J (1995) The ecology of mangrove conservation \& management. Hydrobiologia 295:343-351

Potter IC, Tweedley JR, Elliott M, Whitfield AK (2014) The ways in which fish use estuaries: a refinement and expansion of the guild approach. Fish Fish 16:230-239. https://doi.org/10.1111/faf.12050

Ruman M, Kozak K, Lehmann S, Kozioł K, Polkowska Z (2012) Pollutants present in different components of the Svalbard archipelago environment. Ecol Chem Eng 19:571-584

Samecka-Cymerman A, Wojtun B, Kolon K, Kempers AJ (2011) Sanionia uncinata (Hedw.) loeske as bioindicator of metal pollution in polar regions. Polar Biol 34:381-388

Sogard SM (1992) Variability in growth rates of juvenile fishes in different estuarine habitats. Mar Ecol Prog Ser 85:35-53

Storelli MM, Storelli A, Marcotrigiano GO (2001) Heavy metals in the aquatic environment of the Southern Adriatic Sea, Italy. Macroalgae, sediments and benthic species. Environ Int 26:505-509

Thonon I (2006) Netherlands Geographical Studies 337: deposition of sediment and associated heavy metals on floodplains.: c/o Faculteit Geowe tenschappen, Universiteit Utrecht

Tunde OL, Oluwagbenga AP (2020) Assessment of heavy metals contamination and sediment quality in Ondo coastal marine area, Nigeria. J Afr Earth Sci 170:103903

Udechukwu BE, Ismail A, Zulkifli SZ, Omar H (2015) Distribution, mobility, and pollution assessment of $\mathrm{Cd}, \mathrm{Cu}, \mathrm{Ni}, \mathrm{Pb}, \mathrm{Zn}$, and $\mathrm{Fe}$ in intertidal surface sediments of Sg. Puloh mangrove estuary, Malaysia. Environ Sci Pollut Res 22:4242-4255

USEPA (2007a) Method 3050B: acid digestion of sediments, sludges, and soils

USEPA (2007b) Method 3051A: microwave assisted acid digestion of sediments, sludges, soils, and oils

USEPA (2007c) Method 6010: inductively coupled plasma-optical emission spectrometry (ICP-OES)

Vallee BL, Ulmer DD (1972) Biochemical effects of mercury, cadmium and lead. Annu Rev Biochem 41:91-128

van den Heuvel-Greve MJ, Szczybelski AS, van den Brink NW, Kotterman MJJ, Kwadijk C, Murk A (2016) Low organotin contamination of harbour sediment in Svalbard. Polar Biol 39:1699-1709 
VROM (2016) Dutch Target and Intervention Values, 2000 (the New Dutch List)

Wan Z, Ji S, Liu Y, Zhang Q, Chen J, Wang Q (2020) Shipping emission inventories in China's Bohai Bay, Yangtze River Delta, and Pearl River Delta in 2018. Mar Pollut Bull 151:110882

Weinbruch S, Wiesemann D, Ebert M, Schütze K, Kallenborn R, Strom J (2012) Chemical composition and sources of aerosol particles at Zeppelin Mountain (NyÅlesund, Svalbard): An electron microscopy study. Atmos Environ 49:142-150

Wuana RA, Okieimen FE (2011) Heavy metals in contaminated soils: a review of sources, chemistry, risks and best available strategies for remediation. Int Sch Res Netw 402647
Youssef M, Madkour H, El Attar R, Mansour A, Badawi A (2020) Assessment of metal contamination in coastal marine sediments of Makadi Bay on the Red Sea, Egypt. Mar Freshw Res 71:1241-1251

Zhang G, Bai J, Xiao R, Zhao QQ, Jia J, Cui BS, Liu XH (2017) Heavy metal fractions and ecological risk assessment in sediments from urban, rural and reclamation-affected rivers of the Pearl River Estuary, China. Chemosphere 184:278-288

Zulkifli SZ, Ismail A, Mohamat-Yusuff F, Arai T, Miyazaki N (2010) Johor Strait as a hotspot for trace elements contamination in Peninsular Malaysia. Bull Environ Contam Toxicol 84:568-573

Publisher's note Springer Nature remains neutral with regard to jurisdictional claims in published maps and institutional affiliations. 